\title{
THE DEVELOPMENT OF STUDENTS' ENGLISH WORKSHEET BASED ON PHONETIC TRANSCRIPTION AT THE TENTH GRADE OF MA MA'ARIF ROUDLOTUT THOLIBIN METRO
}

\author{
Anggun tika safita dewi*1 \\ ,${ }^{1}$ IAIM NU Metro, Lampung, Indonesia \\ e-mail: *1 anggunsafita5@gmail.com
}

Education is a conscious and planned effort to create a good learning atmosphere and learning process so that students actively develop their potential. But so far the teacher only uses textbooks only to provide material and questions without training students' pronunciation, because in the textbooks the pronunciation is small and even the teacher doesn't pay attention to students in pronunciation. So that development is needed for the learning process. This study aims to develop a Worksheet based on Phonetic transcription class X MA MA'arif Roudlotut Tholibin 28 Purwosari north Metro. This research is a research and development study. The steps in this research are: Potential and Problems, Data Collection, Product Design, Product Revision, Product Validation, Product Trial, Revision After Trial. The results of this study in the form of a Phonetic transcription class X-based Science Worksheet can be used in the learning process at MA Ma'arif Roudlotut Tholibin 28 Purwosari north Metro, based on responses and validator ratings of the developed teaching materials, obtained results categorized as good. This shows that teaching materials developed based on phonetic transcription in class $X$ can be used as teaching materials for MA MA'arif Roudlotut Tholibin 28 Purwosari north Metro students.

Keyword: Developmet material, students' worksheet, Phonetic Transcription,

\section{INTRODUCTION}

Students' worksheet is a teaching material that contains teaching material that contains instructions, a list of tasks, and guidance to conduct activities arranged in such a way that it can be one of the means to assist and facilitate learning activities, so that effective interactions will be formed between participants students with teachers, and can increase the activities of students in improving learning achievement, especially to improve science process skills(Cooney \& Cooney, 2020).

Students' worksheet are sheets containing tasks that must be done by students in the form of instructions and steps for completing assignments.Reasons for taking students' worksheet(Schaub et al., 2013). Phonetic transcription is concerned with how the sounds used in spoken language are represented in written form(Mesgarani et al., 2014). The medium of sound and the medium of writing are of course very different, having absolutely no common forms or substance whatsoever, but over the ages 
people have found ways to represent sounds using written symbols of one kind or another, ways that have been more or less successful for their purposes(Kuhl et al., 2003).

Based on pre-survey data result by interview with Mr. Eka Cahyadi, S.Pd and students, researcher found of ten students at $X$ grade of MA. Ma'arif Roudlotut Tholibin Metro still have a problem with their pronunciation that show ten of students have low pronunciation ability. The students still difficult to say in good pronunciation and they not yet understanding about phonetic trascription. So, the researcher will to make the students more understand about phonetic trascrition and more success in their pronunciation(Chang et al., 2010).

To increase student learning motivation in learning english, it is seen to look for approprite and innovative teaching materials to be used $\mathrm{n}$ the learning process. From various previous research results, it was found hat one of the effective teaching materials in increasing students' interest in learning and ability is to use English's student worksheet based on phonetic transcription(Babel, 2012).

\section{RESEARCH METHODOLOGY}

This research is included in pre-research development (Research and Development / R \& D) because researchers want to develop educational products in the form of Student Worksheet / LKPD based on phonetic transcription for high school. In this development research the researcher first made a learning device then the learning device product test was held. Based on the above opinion it can be concluded that research development is a process or activity that produces or perfects the product(metode penelitian kuantitatif, kualitatif,dan RED, 2016).

Understanding development research according to Borg and Gall is a research process used to develop and validate products that are used in education and learning processes(Hall \& Lerner, 2010).

The research and development model that will be applied in this research is the research and development model adopted from steps that refer to Borg and Gall. In full according to Sugiono there are 10 steps in implementing the research strategy, namely: Potential and problems, Data collection, Product design, Design validation, design improvements, Product trials, Product revision, trial use, Product revision, Mass production(Un et al., 2010).

However, in this research and development researcher did not use the steps of research number 8.9 and 10 due to the limited time, energy and cost of the researcher. Research can depart from the existence of potential or problems. Potential is everything that when utilized will have added value. The problem, as noted, is the deviation between what is expected and what is happening(Hidayatullah et al., n.d.2019). 
The problem that can be explored and used as a potential to be utilized in this study is that there is not yet a phonetic transcription based student worksheet that is taught in high school that aims to improve students' pronunciation skills. For collecting data the research use Interview technique, Observation technique, Questionnaire technique. The questionnaire will be given to media experts and material experts to determine the validity of students' worksheets and media evaluation as a reference for revision before the trial. While the questionnaire for students and teachers of English is used to determine the response of students and teachers to the worksheets of students who have developed(Ingleby, 2012).

\section{RESULT}

Research and development as a systematic study of complete scientific knowledge or understanding of the subject under study. This research is classified as basic or applied in accordance with the research objectives, namely to develop learning materials for students' English worksheets based on phonetic transcription. To produce a learning material product that is developed, the researcher uses the research and development procedures used are the Borg and Gall development research model that has been modified by Sugiono and is limited to only seven steps of research and development(Sugino, 2016).

At the potential and problem stage the researchers conducted a pre-research conducted at Ma Ma'arif Roudlotut Tholibin 28 Purwosari Metro Utara, while the researchers conducted to gather relevant information in the field, namely researchers conducting interviews with english subject teachers namely Mr. Eka Cahyadi, S. .Pd. the result is that the learning media used by the teacher are only books, so that it seems that English learning is too monotonous and not yet effective(Afify, 2018). The results of this research are used as a reference in making learning materials used to overcome problems in the field. By looking at the existing problems, researchers are interested in developing students 'teaching materials' English worksheets based on phonetic transcription(Bauman-Waengler, 2015).

After conducting the potential and problem stage the researcher conducted a data collection, at this stage the researcher prepared material in the form of congratulating and complimenting other for tent grade obtained from various sources relevant to the material taken(Hall et al., 2010). Then the researcher also considers the time, cost and matters related to the development of students 'learning materials' English worksheets based on phonetic transcription(Wells, 2006). It is intended that the research carried out in accordance with the target and can be completed properly. The stages in the design development conducted by researchers are a description of students 'learning materials' English worksheet starts from designing the initial appearance of the cover. Then analyze the lesson plans that have been determined, sort out the material that will be included in the worksheet of students. In addition to the material above, it is continued by pouring other ideas such as practice questions and phonetic symbols along with examples(Preston et al., 2011). 
After analyzing the needs the next step is product design. There are a number of things to do in the product development stage of the Students' English worksheet based on phonetic transcription. After analyzing the needs, it is continued by collecting data by conducting a study of the material, teaching materials based on phonetic transcription. Phonetic Transcription was chosen because many of the students are difficult and there are still many mistakes in pronouncing English sentences, so make a learning material based on phonetic transcription that will help students in improving how to pronounce English correctly and correctly(Cox \& Fletcher, 2018). After gathering information, the authors then make the design of students' English worksheets based on phonetic transcription, so that it is beneficial for teachers and students in improving the quality of learning. The next stage is product design from the beginning to the end of the product manufacture(Ferjan Ramírez et al., 2017).
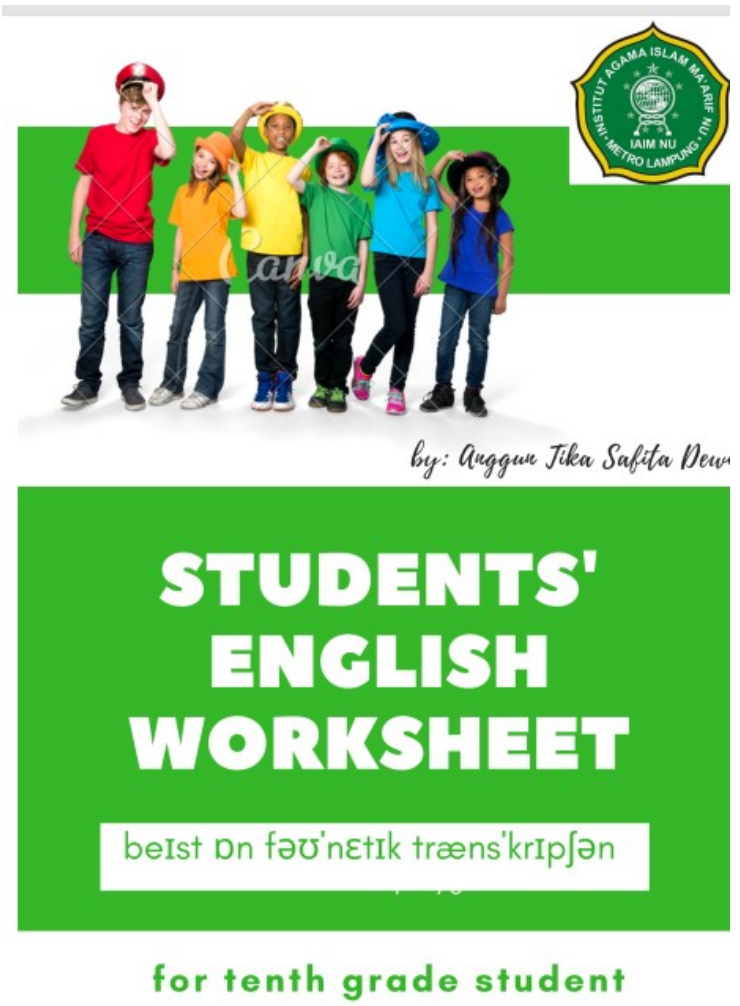

Picture 1. Cover of students' english worksheet based on phonetic transcription.

The covers' color is green because green is the characteristic color of Nahdlotul Ulama'. The researcher input Ma'arif logo in the upper right corner which indicates that this product was made by Ma'arif. The researcher also input picture of overseas children which indicates that it's an English book, and the font style using phonetic style in "based on phonetic transcription("Book Review:Fundamentals of Heat and Mass Transfer," 2007)". 


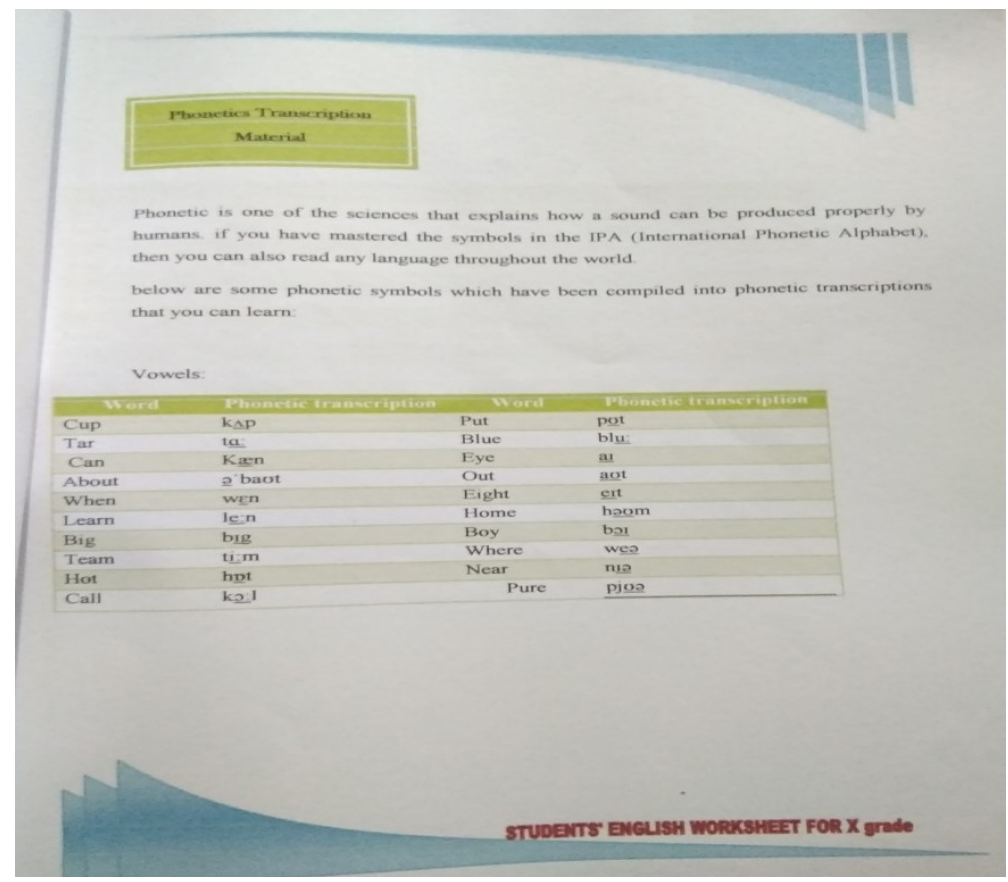

Picture 2. Material of phonetic (vowel)

The picture above is describe about phonetic transcription material that contens is expalnation of phonetic transcription, part of phonetic especially vowel, and the examples of phonetic transcrition (vowel)(Creswell, 2007). 


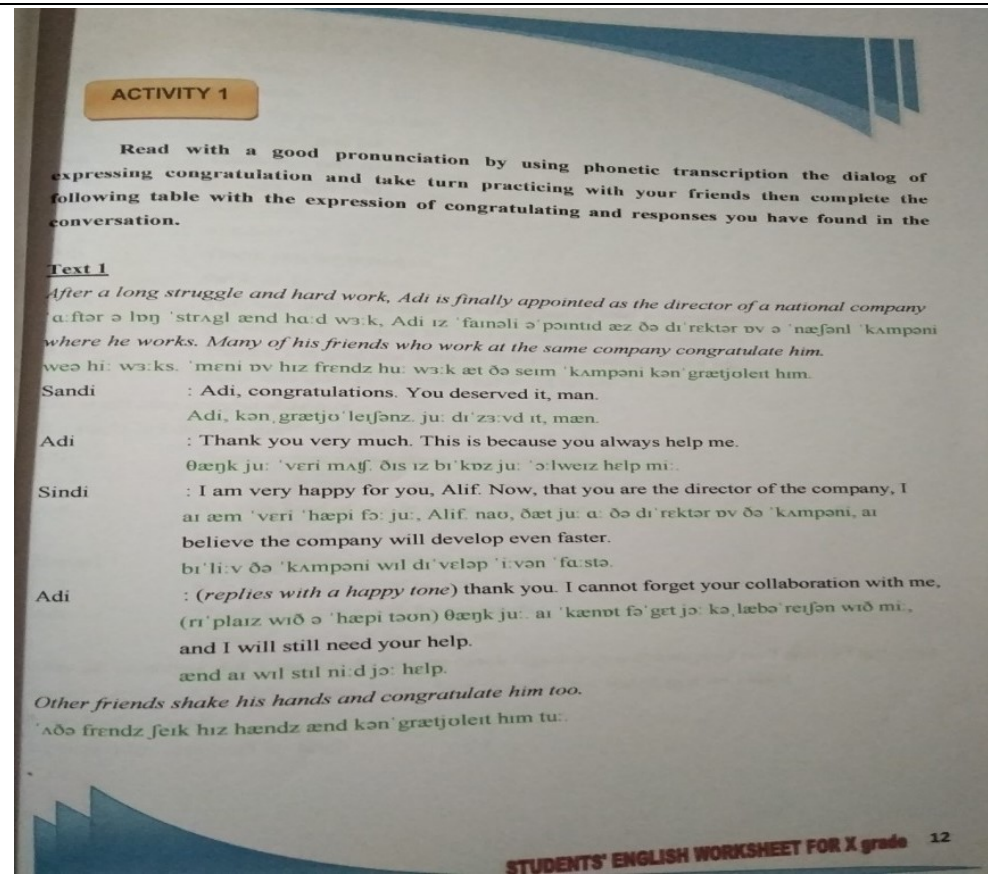

Picture 3. Text material based on phonetic transcription

The picture above is discribe about Text material of congratulation based on phonetic transcription. In that text there is phonetic transcrition under each sentence. The dialog above is expected to help students improve their pronunciation.

After carrying out the product design phase the researcher conducted the design validation while the researcher carried out the stages, namely, the validation of the material experts based on the validation of the material experts carried out in the 2 stages of assessment it was found that the stage 1 of the learning media products was percentage 59\% with the criteria of "quite valid". The initial product was revised in accordance with the input and suggestions for improvement from the material expert validator, while the improvement that needed to be done was less explanation, add page, adjust between text and question. Based on the results of the material tests after revision an percentage of $61 \%$ with "valid" criteria was obtained. In addition to conducting the validation stage for the material expert the researcher also conducted the validation stage for the linguist, based on the validation assessment of the initial product linguist, it was obtained that the language expert validation obtained the following values: on validator 1 , an percentage of $57 \%$ with the criteria of "quite valid", the initial product was revised in accordance with the input and suggestions for improvement from linguist lecturers, as for the improvements that researchers have done that should be consistent in using phonetic (british / american style), be carefull in using structure and grammatical sentences. based on the results of the validation of the media test after the improvement obtained an percentage of $61,5 \%$ with the criteria "valid"(Mahr, 2019). 


\section{DISCUSSION}

Based on the results of the validation carried out by 2 experts, namely 2 lecturers in English IAIM NU Metro Lampung, namely Mr. Irhamudin, M.M, as material expert and Mr. Suhono, M.Pd. as a linguist. after conducting 2 stages of validation by the product validator developed, it is deemed appropriate to use as a learning medium.

Learning media that have been validated by material experts, language experts. Subsequently tested in learning, this trial was conducted by Ma Ma'arif Roudlotut Tholibin 28 Purwosari Metro Utara, where the trial was conducted online with the science class. The results of this trial were conducted by 10 respondents of Class $X$ Natural Sciences by distributing questionnaires. From the results of 10 respondents obtained an percentage result of $81 \%$ with the criteria "very interesting", will be used as a reference to revise the learning media developed. After going through several stages in this research and development, the final results of this study are in the form of learning materials in the form of students' English worsheet based on phonetic transcriptions to facilitate students in learning and improving the pronunciation skills of students Ma Ma'arif Roudlotut Tholibin 28 Purwosari North Metro. Learning materials developed by researchers are in accordance with the steps of the preparation and development of instructional media from the Borg and Gall development model. Namely potential and problems, data collection, product design, design validation, product design revisions, product trials, product revisions. Furthermore, the development of this learning material meets the attractiveness criteria as learning material, in this case the learning material in the form of students' English woorksheet based on phonetic transcription can be used by senior high schools(Mesgarani et al., 2014).

As for the advantages and disadvantages of students' teaching materials, English worksheets based on phonetic transcription. Its strengths are that students work freely, give encouragement to take initiative, be creative and active, increase confidence in learning to solve, handle a problem, facilitate students in learning and improve pronunciation. While the lack of student learning materials' English worksheets is a lack of understanding of the phonetic so that it is a bit difficult for students if without the assistance of the teacher.

\section{CONCLUSION AND SUGGESTION}

The conclusion obtained from this research and development is the teaching materials of students' English worksheets based on phonetic transcriptions produced have been developed with the Borg and Gall model modified by Sugiyono which includes the stages of potential and problems, data collection, product design, design validation, design revision, product trials and product revisions. At the product validation stage conducted by Mr. Irhamudin, M.Pd as material experts and Mr. 
Suhono, M.Pd as linguists obtained an average value with valid criteria, while for language experts obtained an average value with valid criteria.

Teacher responses to students' English worksheets based on phonetic transcription obtained an average score of 92 with very interesting criteria. While the response of students to students' English worksheets based on phonetic transcription obtained an average score of 81 with very interesting criteria.

\section{SUGGESTION}

Teachers should be able to further develop students' learning materials for English worksheets based on phonetic transcription, because these learning materials only contain congratulating and complimenting other materials. Can be added to other materials in order to achieve learning goals.

What is expected by researchers to other research in order to add material and do the preparation of students 'learning materials' English worksheets based on phonetic transcription by adding video links that can support the learning of pronunciation and produce learning materials that are more varied and interesting.

\section{REFERENCES}

Afify, M. K. (2018). The effect of the difference between infographic designing types (static vs animated) on developing visual learning designing skills and recognition of its elements and principles. International Journal of Emerging Technologies in Learning. https://doi.org/10.3991/ijet.v13i09.8541

Babel, M. (2012). Evidence for phonetic and social selectivity in spontaneous phonetic imitation. Journal of Phonetics. https://doi.org/10.1016/j.wocn.2011.09.001

Bauman-Waengler, J. (2015). Phonetic transcription and diacritcs. In Articulatory and phonological impairments: A clinical focus.

Book Review:Fundamentals of Heat and Mass Transfer. (2007). Chemical Engineering Research and Design. https://doi.org/10.1205/cherd.br.0712

Chang, E. F., Rieger, J. W., Johnson, K., Berger, M. S., Barbaro, N. M., \& Knight, R. T. (2010). Categorical speech representation in human superior temporal gyrus. Nature Neuroscience. https://doi.org/10.1038/nn.2641

Cooney, G., \& Cooney, G. (2020). Worksheet 1. In Supporting Children with Fun Rules for Tricky Spellings. https://doi.org/10.4324/9781003011064-2

Cox, F., \& Fletcher, J. (2018). International Phonetic Alphabet. In Australian English Pronunciation and Transcription. https://doi.org/10.1017/9781316995631.011

Creswell, J. W. (2007). Qualitative enquiry \& research design, choosing among five approaches. In Book.

Ferjan Ramírez, N., Ramírez, R. R., Clarke, M., Taulu, S., \& Kuhl, P. K. (2017). Speech discrimination in 11-month-old bilingual and monolingual infants: a magnetoencephalography study. Developmental Science. https://doi.org/10.1111/desc. 12427

Hall, B. H., \& Lerner, J. (2010). The financing of R\&D and innovation. In Handbook of the Economics of Innovation. https://doi.org/10.1016/S0169-7218(10)01014-2

Hall, B. H., Mairesse, J., \& Mohnen, P. (2010). Measuring the returns to R\&D. In Handbook of 
the Economics of Innovation. https://doi.org/10.1016/S0169-7218(10)02008-3

Hidayatullah, R., Saputra, A. A., Amalia, D. R., \& Hasyim, A. A. (n.d.). Schema Activation Strategy in Reading Comprehension.

Ingleby, E. (2012). Research methods in education. Professional Development in Education. https://doi.org/10.1080/19415257.2011.643130

Kuhl, P. K., Tsao, F. M., \& Liu, H. M. (2003). Foreign-language experience in infancy: Effects of short-term exposure and social interaction on phonetic learning. Proceedings of the National Academy of Sciences of the United States of America. https://doi.org/10.1073/pnas.1532872100

Mahr, G. (2019). Validation. Academic Psychiatry: The Journal of the American Association of Directors of Psychiatric Residency Training and the Association for Academic Psychiatry. https://doi.org/10.1007/s40596-019-01138-3

Mesgarani, N., Cheung, C., Johnson, K., \& Chang, E. F. (2014). Phonetic feature encoding in human superior temporal gyrus. Science. https://doi.org/10.1126/science.1245994

Preston, J. L., Ramsdell, H. L., Oller, D. K., Edwards, M. L., \& Tobin, S. J. (2011). Developing a weighted measure of speech sound accuracy. Journal of Speech, Language, and Hearing Research. https://doi.org/10.1044/1092-4388(2010/10-0030)

Schaub, K., Caragnano, G., Britzke, B., \& Bruder, R. (2013). The European Assembly Worksheet. Theoretical Issues in Ergonomics Science. https://doi.org/10.1080/1463922X.2012.678283

metode penelitian kuantitatif, kualitatif,dan R\&D, Alfabeta, cv. (2016).

Un, C. A., Cuervo-Cazurra, A., \& Asakawa, K. (2010). R\&D collaborations and product innovation. Journal of Product Innovation Management. https://doi.org/10.1111/j.15405885.2010.00744.x

Wells, J. C. (2006). Phonetic Transcription and Analysis. In Encyclopedia of Language \& Linguistics. https://doi.org/10.1016/b0-08-044854-2/00014-6

Copyright Holder :

(C) Anggun Tika Safita Dewi (2021).

First Publication Right :

(C) Journal of English Development (JED)

This article is under:

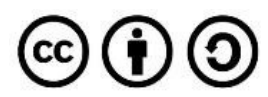

